Article

\title{
City Labs as Vehicles for Innovation in Urban Planning Processes
}

\author{
Christian Scholl * and René Kemp \\ Netherlands; E-Mails: christian.scholl@maastrichtuniversity.nl (C.S.), r.kemp@maastrichtuniversity.nl (R.K.) \\ * Corresponding author \\ Submitted: 2 September 2016 | Accepted: 9 December 2016 | Published: 28 December 2016
}

International Centre for Integrated Assessment and Sustainable Development, Maastricht University, 6211 Maastricht, The

\begin{abstract}
This paper assesses the role of urban experiments for local planning processes through a case-based analysis of the city lab of Maastricht. In conjunction with this, the article offers three contributions, as additional elements. Firstly, the paper develops a set of defining characteristics of city labs as an analytical concept which is relevant for discussions about (collaborative) planning. Secondly, it refines the literature on collaborative planning by drawing attention to experimentation and innovation. Thirdly, the paper assesses the potential of city labs to contribute to the innovation of urban governance. The work draws from the literature on experimentation and learning as well as the literature on collaborative urban planning. In the conclusions, we discuss the potential of city labs as vehicles for learning about new urban planning approaches and their limitations as spaces for small-scale experimentation. The paper is based on research for the URB@Exp research project funded by JPI Urban Europe.
\end{abstract}

\section{Keywords}

boundary work; city labs; co-creation; experimentation; Living Labs; public value creation; urban planning

\section{Issue}

This article is part of the issue "Paradigm Shifts in Urban Planning", edited by Matthias Drilling (University of Applied Sciences and Arts Northwestern Switzerland, Switzerland), Efrat Eizenberg (Israel Institute of Technology, Israel), Janet Stanley (University of Melbourne, Australia), Lee Boon Thong (Nilai University, Malaysia) and Andreas Wesener (Lincoln University Canterbury, New Zealand).

(C) 2016 by the authors; licensee Cogitatio (Lisbon, Portugal). This article is licensed under a Creative Commons Attribution 4.0 International License (CC BY).

\section{Introduction}

Cities face challenges of increasing urban complexity (European Union, 2011). At the same time, high hopes are projected on the role of cities in addressing pressing (sustainability) issues "because they are inclined naturally to collaboration and interdependence" (Barber, 2013; see also Kenniscentrum Stedelijke Vernieuwing [KEI] \& NICIS, 2012). This has fostered a renewed interest in the city as a site of experimentation. Whereas some scholars use the term laboratories rather metaphorically to describe cities (Waste, 1987), others see cities as sites for specific experimentation to test novel approaches (Karvonen \& van Heur, 2014). More recently, experimentation has even been conceptualized as a mode of urban governance (Bulkeley \& Castán Broto, 2013; Evans, Kar- vonen, \& Raven, 2016; McGuirk, Dowling, Brennan, \& Bulkeley, 2015). Especially, in the field of sustainability transitions, experimental approaches have gained prominence as a way to explore possible solutions for urban contexts (Evans, 2011; Sengers, Berkhout, Wieczorek, \& Raven, 2016). However, the role of experiments as a new approach to innovation in urban planning has not been sufficiently assessed.

This paper assesses the role of urban experiments for local planning processes through a case-based analysis of the city lab of Maastricht. The central question is how city labs contribute to the innovation of local planning processes. City labs are a special type of a lab in that the city administration is either the initiator or an important party to it. The term city lab is not a well-defined term and one of the aims of this paper is to better define it. A 
good starting point for this is the descriptions of city labs themselves (Figure 1). From the descriptions, it is clear that the term is used for different types of labs.

In the past decade, there has been a proliferation of labs outside the traditional domain of science and business: living labs, design labs, policy labs, innovation labs, etc.; virtually any aspect of society seems to be suited for a lab. In the urban context, recently the term "urban living lab" has gained traction (Schliwa \& McCormick, 2016; Voytenko, McCormick, Evans, \& Schliwa, 2016). However, there is still no consensus on how to define urban living labs as it is being used as an umbrella term for a broad variety of arrangements.

In this paper, we want to examine city labs as a distinct analytical category to look at urban labs and urban experiments from a planning perspective. The term city lab, as a specific type of urban living lab, emerged from discussions with city lab practitioners involved in our research project and the literature review, both of which showed the need for a new concept. Likewise, the characteristics of city labs became gradually defined (as shown by the graph produced at the first workshop).

City labs are set up for different purposes. They may be used to generate ideas for city projects and explore visions (of sustainability, democracy and devolution of public tasks and responsibilities) or oriented towards actions (with the idea generation and evaluation element as a precursor). And they may be used to experiment with new forms of urban planning. This makes them different from urban living labs in that city labs explicitly involve the local administration and that their goal is not just product or service improvement, but also innovation in planning processes. Technological solutions and scientific expertise play a much less prominent role in city labs than in (urban) living labs. So the term urban living lab does not exhaust the diversity of lab forms in the urban realm, but nevertheless points to an important precursor: living labs.

With their focus on user-centered innovation, living labs are an important inspiration of city labs. By involving potential users in real life settings, user feedback can be integrated and emerging problems of prototypes addressed before bringing a refined product to the marketing stage (Almillal \& Wareham, 2011; Bergvall-Kareborn \& Stahlbrost, 2009; Leminen, Westerlund, \& Nyström, 2012). This approach has spread rapidly with more than 170 active living labs registered in the database of the European Network of Living Labs (ENoLL). However, there is no consensus on how to define a living lab (Veeckman, Schuurman, Leminen, \& Westerlund, 2013); some commonly recognized core characteristics of living labs are that they constitute: (1) long-term environments/platforms with (2) user-centred perspectives using (3) co-creation approaches and (4) local experiments

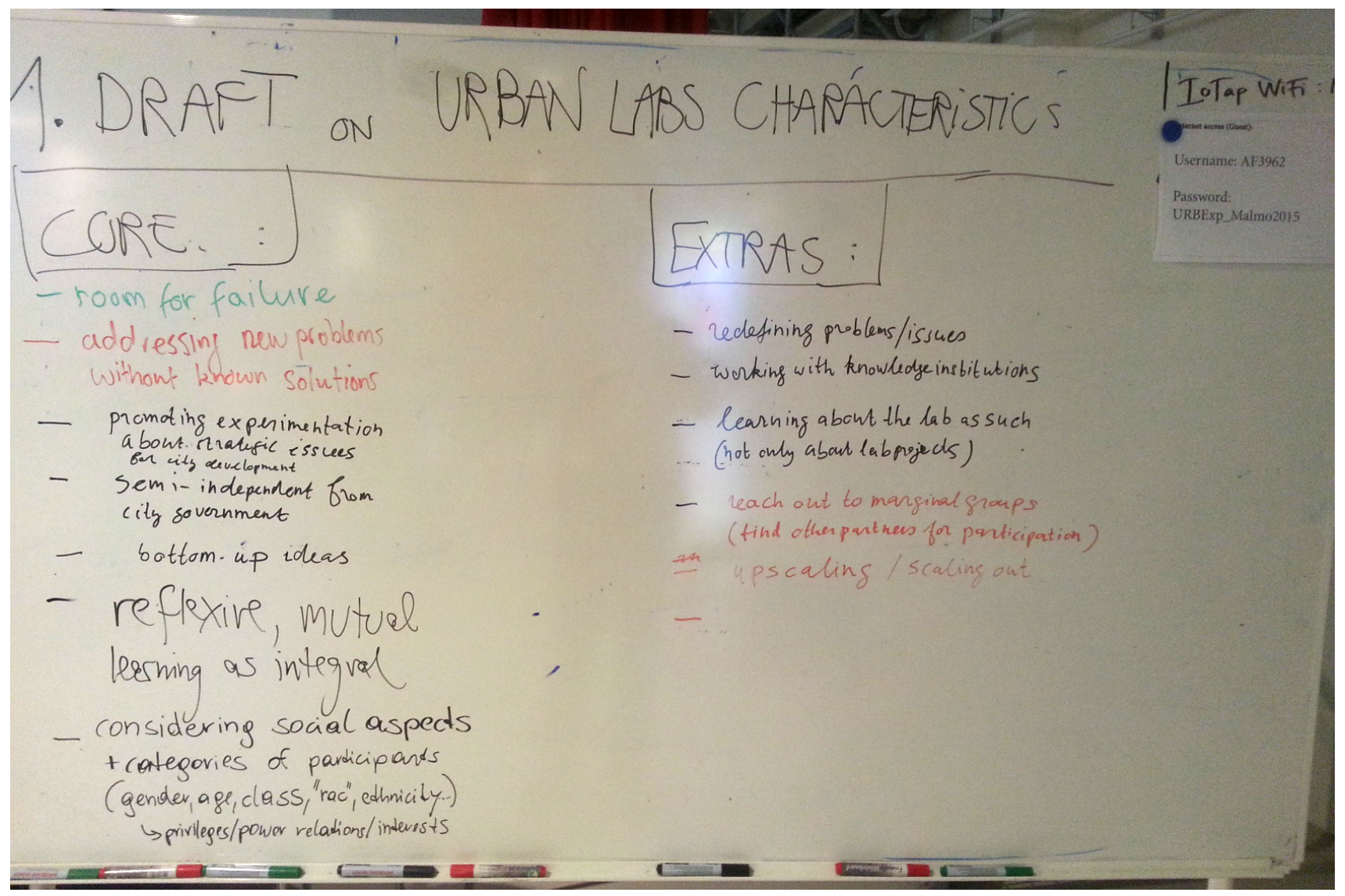

Figure 1. An early collective attempt at defining Urban Lab characteristics by URB@EXP researchers and practitioners. Picture from the URB@Exp project meeting in Malmö, March 2015. 
in real-world contexts (Hellström Reimer, McCormick, Nilsson, \& Arsenault, 2012; Hillgren, 2013).

Another precursor of city labs are design labs. In being less technology-oriented than living labs, design labs are highly relevant to local planning processes, as they apply design-oriented approaches and often focus on urban sustainability. More recently, design labs tend to direct their focus towards broader publics and multiple types of value creation (Björgvinsson, Ehn, \& Hillgren, 2012; Botero \& Saad-Sulonen, 2013; Westley, Goebey, \& Robinson, 2012). Labs relating to the research field of participatory design have focused on power issues and democracy, highlighting the need to include marginalized stakeholders in innovation processes-not only as participants but also as collaborators (Björgvinsson et al., 2012). City labs could be a way forward to learn about the challenges in creating more reciprocal and mutual relationships between citizens, researchers, and public and private sector agents. To achieve this, they are also much more focused on institutional innovation than living and design labs.

City labs are also different from innovation hubs where the generation of new ideas and practices is much more central than learning about planning processes. Moreover, innovation hubs do not necessarily aim to address an urban challenge or social problem, but rather aim to unleash the creative and innovative potential of their participants (Gabriel, 2014).

In this paper, we are especially interested in the influence of experimental learning in city lab projects on urban planning. The paper is based on an explorative investigation which looks at the role of experimentation and the use of boundary work in overcoming resistance to innovation and fostering changes in urban planning. The question of investigation is examined for the case of the city lab of Maastricht. M-LAB (Maastricht-LAB) is considered by the authors of this paper to be a good choice for investigating the influence of experimental learning on urban planning since M-LAB was set up with the express purpose of innovating and changing city planning. Investigation of the M-LAB as a research case is facilitated by the close cooperative relationship between the authors of the paper and city lab officials, which allows for a transdisciplinary analysis.

The city lab of Maastricht was set up in 2012 by the department of spatial planning of the municipality of Maastricht as a temporary platform for local experimentation and learning by doing. Since the start of the economic crisis in 2007, the urban planning and development landscape has changed rather dramatically in Maastricht (and other cities in the Netherlands) with the breakdown of several large public-private partnerships as a result of both demographic and economic stagnation. To safeguard the urban quality of Maastricht in the absence of new large-scale plans and projects, the municipality wants to stimulate a transition towards novel modes of urban development. Official elements of this transition are the repurposing of empty buildings, incremental and small-scale development, temporal use, flexibility, sustainability, co-creation, and bottom-up initiatives (Gemeente Maastricht, 2012).

The influence of M-LAB on the spatial planning system in Maastricht is investigated with the help of a set of questions regarding outcomes and mechanisms which are structured into 5 rubrics:

1. Lessons learned: To what extent did the project learn lessons about new forms of urban planning? What did the lessons consist of? What role did the city lab play in obtaining and disseminating such lessons? Did the city lab learn important lessons about its own functioning?

2. Co-creation ${ }^{1}$ : What did the co-creation consist of? Who was involved in the co-creation process (and who was not)? What problems did the actors encounter in the co-creation process? How were such problems overcome?

3. Boundary work: Were boundaries of policy and knowledge production being crossed? Was policy making and knowledge production a joint task? Did some people act as boundary workers? Did the city lab act as a boundary organization between policy and practice/society, and if the city lab did act as a boundary organization, in what way did it do that?

4. Public value creation, openness and reflexivity: How open and reflexive was the process. How was the public interest maintained?

5. Overcoming resistance to institutional innovation and innovation achieved: Was the city lab instrumental in helping societal actors do something innovative (in the form of an urban development project)? What did the innovation in urban planning consist of?

The research answers to those questions are used to address critical issues in relation to the functioning of city labs such as:

- How to maximize the contribution of lab-projects for innovation in urban planning?

- How to secure and maximize public value for the city in city lab urban development projects? How to make city labs more inclusive and socially responsive?

The findings presented in this paper are an outcome of the URB@Exp project on urban labs as new forms of ur-

\footnotetext{
${ }^{1}$ In this paper, the term "co-creation" instead of the term "collaborative planning" is preferred because of the prominence of the co-creation element (doing something novel through a co-development partnership), and because the collaborative element is circumscribed and project-specific (it is high for those officials who actively contributed to the co-creation process and low for others). Collaborative planning is a valuable concept but like any concept it has its limitations (a discussion of "cracks within collaborative planning" is provided by Brand and Gaffikin (2007).
} 
ban planning. In this three-year research project funded by JPI Europe, one foresight company, four universities and five city partners (Antwerpen, Graz, Leoben, Maastricht and Malmö) jointly engage in transdisciplinary action research to establish guidelines for urban labs. The findings are based on regular interactions with the members of M-LAB consisting of interviews with M-LAB coordinators, participants in the lab projects, research by a Master's student on M-LAB projects, participant observation, a workshop with organizational experts who reviewed the $M-L A B$, discussions about lessons that were learned and the role of boundary work. Lab participants came to our project meetings and engaged in discussions about issues of definition (what is a city lab) and were actively involved in exercises to learn more about their own lab. In the project, there were special sessions about this. The research for this wasn't based on strict methodological rules but was conducted in the spirit of transdisciplinary research (as defined by Pohl \& Hadorn, 2008): descriptively rich, with exercises to learn more about their own lab attention to perceptions and actor-specific understandings, and with interpretations being discussed with those who are researched, in particular, Tim van Wanroij of M-LAB.

Boundary work, reflexivity and public value creation were not part of the framework but were added on the basis of the action research. Boundary work seemed to be a useful concept for making sense of knowledge integration and interest integration. It refers to the management of institutional junctions through a coproduction process in which formal responsibilities are de-emphasised in the direct cooperation process and re-emphasised towards the outside world and at critical moments in the cooperation process (cf. Hoppe, 2010; Kemp \& Rotmans, 2009). Boundary work helps to overcome institutional boundaries between science and policy, between city administration and societal actors, and between different types of knowledge holders by accepting different types of knowledge as relevant. By de-emphasising that one is a public administrator, labofficials were able to be actively involved in the creation of actor's networks, the improvement of lab projects whilst serving as gatekeepers with respect to the city administration and policy (by partially taking over this task from stakeholders). The importance of reflexivity (learning about the Lab as such) was shown to be an important topic together with public value creation (which was approached too implicitly). This shows the power of an inductive approach but also the importance of theory (analytical concepts for empirical phenomena).

The structure of the paper is as follows. In section 2, we present our theoretical perspective combining theories on experimental learning with the literature on (collaborative) urban planning. Section 3 starts with a short description of the case of the Maastricht-LAB and then discusses its contribution to the innovation of local planning processes by looking at the five aforementioned is- sues. In the last section, we return to our main argument, i.e. that city labs have potential to be vehicles for learning about new forms of urban planning and how the potential for innovation in local urban planning processes can be enhanced. We also stipulate a research agenda for examining and maximizing their impact in terms of added public value.

\section{Innovation in Urban Planning Processes by City Labs}

From the literature on innovation and experiments we know that innovation requires knowledge (possessed by different actors), financial resources and cooperation among actors with different interests, resources and perspectives (Dyer \& Singh, 1998; van de Ven, 1986). Innovation is a journey of learning and discovery in which setbacks are frequently encountered, in which projects may cohere towards new ideas and partners, and in which the environment-is not just something external but something conducive to re-interpretation and manipulationoffers constraints and opportunities (Van de Ven, Polley, Garud, \& Venkataraman, 1999). In innovation studies, cocreation is used as a general term for a co-development approach and as a specific term for innovation projects based on co-design by users (Prahalad \& Ramaswamy, 2004). In this paper, the term co-creation refers to an approach in which city officials are actively involved in the design and implementation of city projects in a creative (co-development) way, and not just in a procedural way.

Experiments are special innovation projects whose goal is to learn something rather than to achieve a predetermined outcome (Kemp \& Van den Bosch, 2006). In reality, however, success is an often hoped for outcome of an experiment. An advantage of labelling something as an experiment is that it provides room to fail. Failure, in the sense of unmet expectations, can contribute as much to social learning about new approaches as success. Experiments through real projects generate a unique type of knowledge-experiential knowledgefor stakeholders and a strategic choice of experiment allows them to learn about issues they are interested in (Kemp, Schot, \& Hoogma, 1998; Thomke, 2003). What is being learned (or can be learned) depends on their design: a well-planned experiment helps to avoid common mistakes, such as insufficient user involvement and an overemphasis on learning about technical aspects (technology testing) (Hoogma, Kemp, Schot, \& Truffer, 2002). In $M-L A B$, lessons were actively sought regarding the temporary use of buildings and the flexible use of regulations, through the use of projects that facilitated learning about those issues. If insufficient attention is given to mechanisms and to special conditions, learning is likely to be superficial. We should also note that real-life experiments based on stakeholder's interests differ from scientifically controlled experiments. ${ }^{2}$

An interesting category of innovation is the creation of institutional vehicles for innovation ("innovation for

\footnotetext{
${ }^{2}$ Non-controlled experiments are called quasi-experiments (Babbie, 2008, p. 397).
} 
innovation"). City labs fall into this category. Apart from stimulating urban development projects, city labs can use co-creation to perform experiments which mirror their ambition to learn about new approaches to local planning processes. This is a highly distinctive feature since local governments do not usually engage in experiments but develop and apply procedures that deliver guaranteed results. In this paper, the role of the city lab of Maastricht in fostering changes in local planning processes through urban development projects will be studied.

Innovation projects may be divided into those in which the aim is to produce a material product and those in which the aim is a new social practice. In the context of urban planning the innovations are less about a product or service for consumers but about public-private community issues such as the use of public space and regulations, citizen or expert tables to discuss urban futures, devolution of government responsibilities to nongovernment bodies, and the creation of space for citizen initiatives. Exemplary innovations are the repurposing of a building combining multiple functions, the flexible use of regulation, the temporary private use of public space (by and for the local community), and new forms of citizen participation in urban planning. Acceptability is an important element of urban innovation projects and is more easily gained through cooperation when there is an interdependency of interests than through technocratic decision. Dialogue and cooperation build credibility more than expert models which often run into problems of non-acceptance, by disregarding the communities' desire for consultation and co-creation (as shown by several cases in Grönlund, Bächtiger, \& Setälä, 2014 and Innes \& Booher, 2010). The literature on collaborative planning offers important insights on this matter.

Urban planning is not only a technical but also a political process including the planning of the built environment, the use of land and environment, public welfare, and the design of the urban environment (Levy, 2016). It is about the practices of urban planners, but the formal planning process is part of a bigger planning process: In the larger context of different realities and rationalities of actors, "formal planning becomes only one component of the whole planning process.... broader, more evolutionary notion of the planning process is needed to account for different realities" (Reich, 1975, p. 11). To deal with the limitations of 'traditional' (urban) planning based on prescription, Healey (2006) and Meadowcroft (2007) propose more relational and reflexive forms of governance and planning. Relational forms of planning are based on co-governance arrangements. Reflexivity has different interpretations. Meadowcroft links reflexivity to the transformation of the governance system itself and the search for innovative solutions to social problems by moving beyond surface manifestations to uncover structural and systemic underpinnings. Healey (2007), in her work on relational planning, stresses that transformations in governance have a discursive ele- ment: of actors creating meaning to issues and possible intervention strategies, which such meaning depending on frames and people's experiences and, as she puts it, "transformation of governance landscapes thus involves struggles over materialities and meanings, over access to material resources and to regulatory authority, over creating frames of reference which shape governance attention and mould practices" (Healy, 2007, p. 24).

These experts do not propose that traditional forms of governance are stripped down, but rather propose more reflexive modes of decision-making in which each case is considered on its own merit, to create public value through innovative solutions and policy strategies. The public value may lie in economic, social and ecological benefits, both in public and private spheres. Relational and reflexive forms of urban governance have drawn considerable attention in planning theory and practice, emphasizing deliberative and participatory processes. However, many exercises in collaborative planning turn out not to be so collaborative at all (Brand \& Gaffikin, 2007). They run into similar problems as the well-known dilemma of "participation as windowdressing" (Arnstein, 1969).

The use of regulation is a form of planning, as is the use of informal consultation in conjunction with formal procedures. Planning practices are based on planning theories but are very much open to other influences. In collaborative forms of planning (Healey, 1997, 2003; Innes \& Booher, 2010), actors (of government and stakeholders outside government) engage in dialogue to produce innovation in the policy system and the urban environment, to co-create solutions that are acceptable and credible for those involved (Figure 2).

The collaborative forms of planning resemble innovation projects in that no actor is in full control of the process, and in that the actions are based on dialogue which is oriented towards learning (about substantive issues but also about acceptability and people's frames), and the integration of knowledge and mediation of interests in a non-coercive way. What makes innovation in urban projects different from innovation for consumers is that public interest needs to be safe-guarded (as well as the interests of those involved) and that the government still assumes an important role as a regulator, funder and authority with veto power. For reasons of public accountability and legal requirements, cities and towns have developed bureaucratic ways for dealing with built environment issues that constitute the basis for decisionmaking and thinking. Many administrators and policymakers see the need for a different model of urban governance, but they are struggling to determine how this can be achieved.

Most planners know very well that the requirements they adhere to for reasons of law and equal treatment may; stand in the way of innovation, be a source of conflict with external actors, and give rise to internal discussion and interpretations. City labs are a way of getting around the formal bureaucratic system in a quasi-formal 


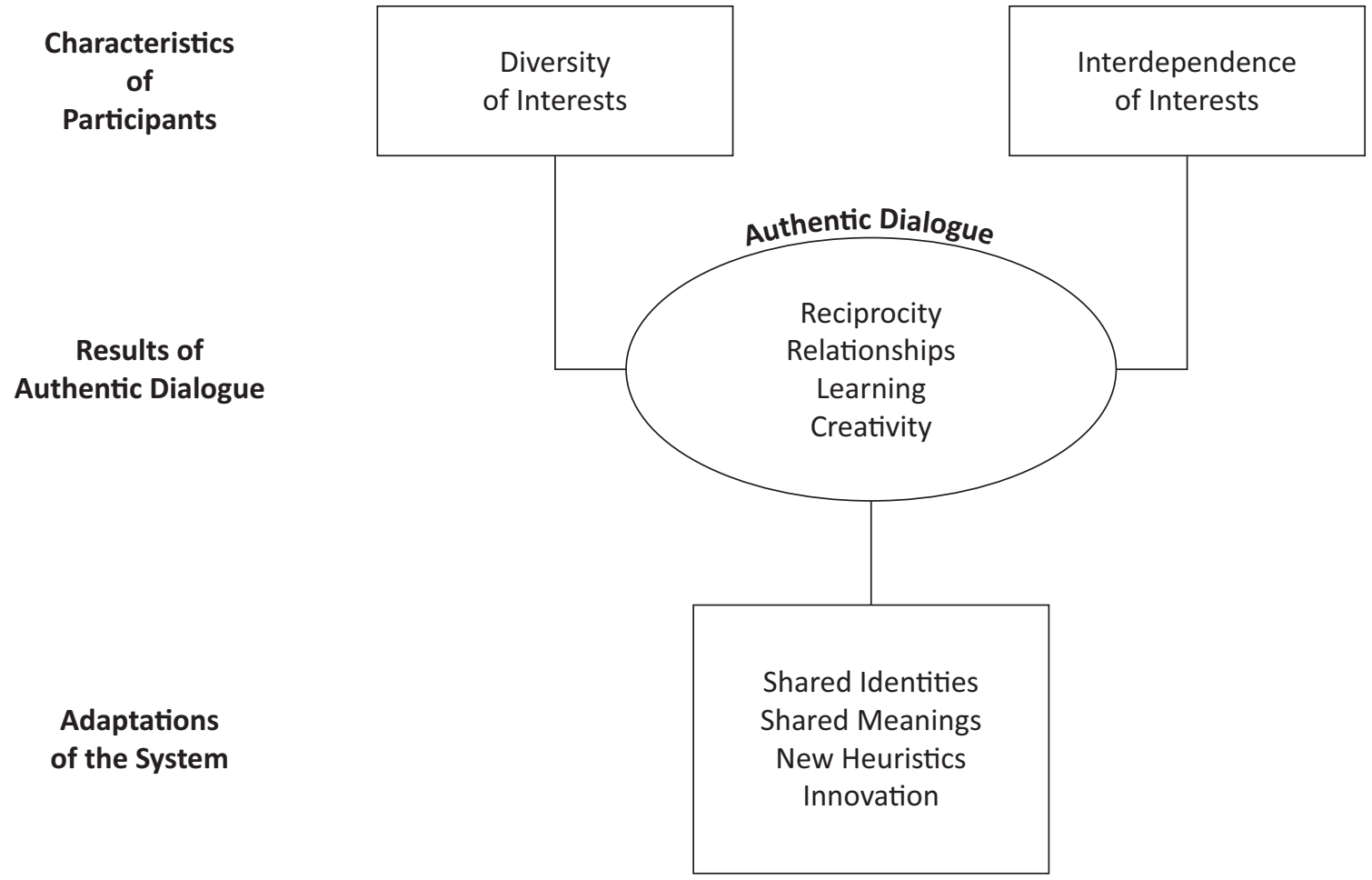

Figure 2. The integration of the diverse, interdependent interests through authentic dialogue as a way to achieve change in the policy system and urban environment (Innes \& Booher, 2010, p. 35)

way, by allowing certain deviations. The lifting or softening of requirements may be done by the participants in the city lab themselves or by the formal authorities on the basis of advice from city lab practitioners. In the case of city labs, new forms of urban planning may even be actively investigated for strategic reasons, as happened in the case of Maastricht.

This is why a city lab can be seen as a collaborative form of planning alongside other forms of planning, with which it has an intricate relationship. Its position vis-àvis the policy system allows it to be instrumental in having an influence on the policy system and on projects that are being carried out. The influence of the city lab on the policy system and local planning procedures increases when the projects are done with the aim of learning about new forms of urban planning. The influence also depends on the lesson drawing activities of the city lab and the receptiveness of the urban policy system to change.

To investigate the role of city labs as being mediating organizations between urban development projects and the policy system, we will use the term boundary work. Boundary work refers to the management of boundaries. What happens in boundary work is that "the demarcation of something against something else" is either emphasized or de-emphasised. The knowledge of a scientific report or testimony of a scientist may be emphasized as "knowledge from science" by the scientist or government who wants to rationalize a certain choice, or de-emphasised in recognition of (expert) knowledge of business actors and (situational) knowledge and lifeworld concerns of citizens. ${ }^{3}$ The notion of boundary work has proven its value for understanding practices of meaningful interaction between actors in different domains (Gieryn, 1983; Hoppe, 2010). Applied to science policy interactions, the concept assumes that the boundaries between science and policy are not fixed, but continuously discursively determined and negotiated by the actors in, and in between, both domains. It is also suggested that the interface between science and policy may be bridged by boundary workers or boundary organizations with the help of boundary concepts. Boundary work can be done by individuals acting in an ad hoc capacity in policy settings and by institutionalized boundary organizations (Cash et al., 2003; Guston, 2001). In our analysis of urban processes of co-creation we will investigate to what extent boundary work is assisting the integration of knowledge, concerns and interests in city projects, planning processes and practices.

\section{The Maastricht-LAB's Contribution to the Innovation of Local Planning Processes}

In this section the city lab of Maastricht is introduced and then discussed with reference to five analytical dimensions-experiments and learning, co-creation,

\footnotetext{
${ }^{3}$ An empirical description of boundary work-in the form of the co-production of a new strategic framework for energy innovation policy in the Netherlands-is provided in Kemp and Rotmans (2009). A discussion of critical conditions for joint knowledge production can be found in Hegger, Lamers, Van Zeijl-Rozema, and Dieperink (2012) and Hegger et al. (2013).
} 
boundary work, social responsiveness and criticism-to illustrate how city labs can contribute to the innovation of local planning processes. Since M-LAB's way of working was quite different in its first (2012-2014) and second phase (2014-2016), we flesh out the differences where necessary.

\subsection{The Maastricht-LAB (M-LAB)}

Maastricht is a medium-sized Dutch city $(120,000$ inhabitants), and the capital of the Province of Limburg, close to the borders with Belgium and Germany. For decades, urban development in Maastricht was growth-driven by public-private partnerships and large-scale master-plan projects. Since the start of the economic crisis in 2007, the municipality has wanted to stimulate a transition towards new modes of urban development focusing on repurposing of empty buildings, incremental, small-scale development, temporal use, flexibility, sustainability, cocreation, and bottom-up initiatives. Having lost a number of key partners for large-scale master-plan projects, there was greater space and need for more participatory approaches mobilising citizens and local organisations for concrete urban development initiatives and projects. These plans were set out in a new long-term strategy for spatial planning (Gemeente Maastricht, 2012), briefly announcing the creation of Maastricht-LAB (M-LAB) as an experimental space and temporary governance platform with the aim of learning about new modes of urban development and planning.

M-LAB has a hybrid position and is placed partially outside of the municipality: institutionally, by the fact that it has an external partner as one of the two project leaders, and physically, with temporary office spaces being outside the municipality buildings. The alderman responsible for spatial planning and environmental issues holds the political responsibility; the manager of spatial planning is involved from a policy perspective and gives managerial back-up. The activities of M-LAB are built upon three pillars: the development of new coalitions (connecting), implementation of local experiments (acting) and the creation of a broad knowledge infrastructure (learning).

In the first phase (2012-2014), M-LAB conducted eight experiments, seven of which were initiated by the municipality. Every experiment addressed different challenges and specific research questions. The results were documented in so-called Lab-journals publicly accessible on M-LAB's website. In the second phase (2014-2016), $M-L A B$ acted as a facilitator and transferred the initiative to the public and local (professional) organisations through a "permanent open call." Project proposals had to meet four criteria:

1. The project had to be innovative and contribute to a new way of urban development (content);

2. The project had to result in value creation in the broad sense (economic, spatial, social) (value);
3. The project had to be an example for the city and transferable to elsewhere in the city (exemplary character);

4. The initiator had to be able to carry the final responsibility for the project (clear project owner).

At the time of writing this paper, M-LAB is completing the second phase and preparing for a third one, again with a slight shift in focus.

\subsection{Lessons Learned}

M-LAB was explicitly set up by the municipality to experiment with new forms of urban planning and development. The Structure Vision 2030 for spatial planning and urban development in Maastricht announced the creation of the city lab: "In the Maastricht-LAB, the municipality of Maastricht will actively search for new (spatial and financial) instruments. We do so together with all parties who are shaping the city" (Gemeente Maastricht, 2012). This was a remarkable choice. Bureaucratic administrations usually stick to established rules and procedures in order to produce secured (relatively certain) results in a legitimate way. Experimenting means that the outcome is uncertain and that there is potential for failure, but on the other hand, there is the potential to discover something highly innovative.

During the first phase, M-LAB conducted 8 experiments, seven of which were concluded. For most of them, a so-called LABjournal was written to describe what had been done and to record the main lessons that had been learnt. The topics of these experiments varied widely but always had a connection to spatial planning practices and/or real estate development. The experiments were either chosen by the M-LAB team or proposed by the municipality. The Guideon's group, an advisory group of 17 urban professionals with varying backgrounds discussed each experiment with the M-LAB team in advance and afterwards. Through this practice, they also contributed to the learning process in the first phase. Another instrument for learning and sharing the lessons of M-LAB experiments is the StadAcademie (City Academy) set up towards the end of the first phase, formalised through its own foundation, run by the external project leader of that time and co-funded by the department of spatial planning.

For the last experiment of the first phase, M-LAB invited citizens of Maastricht to propose their own ideas. The sheer quantity of proposals received (49) and the overall quality of the incoming proposals was one of the reasons for changing the way of working in the second phase. From that point onwards neither, M-LAB nor the municipality initiated experiments. The work of the Guideon's group was discontinued (in part because of negative publicity in the local newspaper about this being an urban development clique). A new, more open network was established: with citymakers providing input to the $M$ LAB team. Through a "permanent open call" citizens were 
encouraged to submit their own proposals. Selection of proposals by the M-LAB team was based on the four criteria aforementioned: content, value, exemplary character and clear project owner. Out of several dozen proposals, M-LAB facilitated 14 experiments throughout the second phase. Several of the non-selected projects were helped by redirecting them to other units of the municipality.

The topics to learn about remained the same in the second phase: re-purposing of empty buildings, flexible and temporary use, incremental, small-scale development, sustainability and co-creation. The character of the experiments, however, changed significantly from the first to the second phase. During the first phase, the $M-L A B$ team defined a number of questions and issues that were to be investigated in an experiment, beforehand. For the very first experiment with a potential park in an old industrial area of the city being re-developed, the following questions provided guidance: What is the role of a park in the $21^{\text {st }}$ century? How can policy participation take place through an open process with stakeholders involved in the design phase? Who is the end user of this area and which responsibilities would they be willing to take? How can connections be made, for example between the past and the future? This way, it was clear, what the experiment was about, and also the learning could be moved in a clear direction.

During the second phase, these questions were formulated as soon as a project proposal came in. However, the outside party's focus is not necessarily to learn, but certainly to get their project proposal implemented. The solution for a problem was thus pre-defined and not always open for debate and investigation. This shift was reflected by a change in terminology, for example, M-LAB's website no longer talked about experiments but about projects. Much more than learning about novel forms of urban development (such as the temporary use of vacant space), M-LAB was learning now more generally about steering local planning processes in the role of facilitator and partner of projects, run by other organisations and individuals. Finally, by helping outside parties to implement their project proposals, M-LAB became more focused on having an added value for an initiative. Since value added by M-LAB can be rather small, it becomes more difficult to tell when an experiment with the role as facilitator actually failed and when it did not.

\subsection{Co-creation}

Co-creation was the main starting point for every experiment and was based on a process in which multiple organisations and stakeholders participated on an equal basis throughout the whole process. Throughout both phases, M-LAB's approach to co-creation never really became scripted but was conducted on a case-by-case basis. Co-creation consisted of two types: the use of transdisciplinary knowledge production, and a new form of policymaking and implementation in which active citizens and shared ownership of the process are crucial elements.
Transdisciplinary knowledge production in M-LAB's first phase consisted of many types of interaction between city officials from various departments, e.g. cultural heritage and permission with various groups of citizens, from young entrepreneurs to cultural organizations, architects, project developers, academics and people from the cultural sector. In the second phase, after the discontinuation of Gideon's group, transdisciplinary knowledge production was taking place in the meetings with the network of citymakers, where also some topics for future experiments were explored, in multi-disciplinary workshops related to specific projects, in public events organized by M-LAB, in the Dutch Cities in Transition network and through participation in research projects such as URB@Exp.

Two examples cases of co-creation are the repurposing of the old fire brigade station and the creation of a plan for the future transformation of the limestone mine at the border of Maastricht. In the case of the fire brigade station, the co-creation process consisted of a reversal of the planning process: instead of first developing a concept for the building and then finding a user who wants to exploit that concept, M-LAB invited a potential group of users to collaboratively develop a concept for the building with them. This turned out to be a combination of flexible and partly collaborative office spaces, with a café and a multi-use space for neighbourhood and citizen initiatives. Hence, the experiment and learning took place in a multi-stakeholder constellation and the municipality had an entirely different role than it usually has in such re-purposing projects. Many, but not all, of the external participants decided to also participate as users of the re-purposed fire-station.

In the case of the transformation of the limestone mine into an area of recreation and nature, different stakeholders were brought together in a workshop to establish a plan for the temporary use of a specific zone during the time where the mine was to be transformed. Participants consisted of neighbours and a citizen association protesting against the mine and a number of experts from the world of architecture, planning, geology and ecology. In the workshop people were split up into three groups to create concrete proposals, with each group consisting of a mix of people. The proposals were used by a team of responsible architects to create transformation plans. In a feedback workshop, all participants expressed satisfaction about the way their input was incorporated into the plans.

During the second phase, the second form of cocreation received more attention owing to the decision of the M-LAB to take a less active role in the formulation and initiating of projects. Discussions with transdisciplinary researchers of the URB@Exp project resulted in the identification of 4 roles: advisor, broker, partner, and accelerator. We had conversations with the external project initiators and they confirmed the ideas that the M-LAB team already had about their role. 


\subsection{Boundary Work}

M-LAB sees itself quite explicitly as a municipal project with a hybrid organizational form that works at the interface of the municipal apparatus and society in order to investigate how the separation between both can be bridged. Indeed, M-LAB can be seen as an institutionalized boundary organization enabling new ways of thinking and new practices by bridging different domains. During the first phase, for example, the M-LAB team examined the idea of organic and preparatory planning. Experiments with two potential parks in a former industrial area to be redeveloped were used as sites to explore possible functions of these parks and of these sites for the re-development of the entire area (the experiment was called "Park of the Future"). To do so, interested cultural organizations were connected to the knowledge realm of urban planners to inspire the further planning process. This was new for the cultural organisations and the city, each of which took on a new role as an example of boundary work. The result was a new concept which made the idea of organic planning more concrete and is now feeding into another planning process of the municipality: start-up image planning. Instead of having a clear image of the final result, a start-up image is created that invites to start exploring the potential of an area.

Another case of boundary work took place around the creation of a creative hub (called Caracola) in an old school. The idea for this came from squatters; M-LAB liked the idea but foresaw problems with the city administration because of a big difference in culture between the creatively minded people who lacked business knowledge and respectability, and the administrators who wanted the proposal to fit with the administrative rules. In one of the meetings it was even said by a city official that the proposal had to be "in the form of a parcel which fitted the drawers of the administration". To bridge the different worlds, M-LAB organized several meetings and talked to each of the parties independently. It also was instrumental in finding a creative solution consisting of an affordable temporary space and permission to use using an abandoned school building for 2.5 years. However, when the Caracola initiators said they wanted to receive money for the 'publicly orientated services' they would provide (e.g. social events, collaborating with citizens and neighbourhood teams), the M-LAB refused because Caracola was not part of the city organization, but a private initiative.

The decision to place M-LAB in a separate building marked a boundary with the city administration. It signalled to external parties the special status of the Lab. Formally, however, M-LAB is part of the city organization and some parties were very surprised to learn this. It is telling that after two years of working for the municipality, the internal M-LAB coordinator still gets asked whether he is working for the municipality by colleagues from the city administration. This situation has arisen as a direct effect of working in a separate building, a de- cision about which they are happy. The blurring of responsibilities is perhaps strongest in the stadsnatuurvisie project, a platform to discuss the future of nature in the city. In this project, initiated by the local nature and environmental organization IVN, the city is involved both via the steering group and as funder. The usefulness of such an arrangement remains to be seen.

In general, boundary work arrangements and activities have helped to create space for new projects, new ways of working and new forms of collaboration. However, a boundary work approach also has disadvantages, as demonstrated by a failed experiment which attempted to provide a local school with sustainable energy. In this specific case, the blurring of roles and responsibilities proved to be a problem. It was unclear whether the M-LAB or the school was the project leader. In the second phase, M-LAB takes a clearer line on this: they do not assume a role of project owner. Their main role is that of matching. Matching requires listening well to the needs of initiators, potential partners and certain administrative units. It also requires a good overview of the field and other initiatives. These are quite different qualities than the ones of the expertise-based city official who operates on the basis rules. The role of M-LAB as boundary organizations hence strongly hinges on the two project leaders as facilitators and boundary workers. Having two coordinators, one from the municipality and one from outside (in the second phase, from the world of business) has proven to be useful to accomplish the task of boundary work. Whereas the internal M-LAB coordinator often makes the matches with respective municipal departments and services, the external project coordinator draws on their network in the local business and development world. In contrast to the internal coordinator, the external coordinator usually emphasizes that they are a person of business, rather than a civil servant. The accessibility of the M-LAB (low threshold) and quick action are highly valued.

\subsection{Public Value Creation, Openness and Reflexivity}

From the start, the Maastricht-LAB followed a procedural approach to social responsiveness and included social and urban stakeholders in order to remain alert regarding unaddressed social needs. In the first phase, this was accomplished mainly via the Guideon's group who discussed possible new experiments with the M-LAB team (introduce), and helped them to evaluate those which had been completed. However, M-LAB was also socially responsive in a more ad hoc manner, by reacting to repeated questions about the possibility of establishing a creative hub for start-up enterprises in the city. This led to the co-creation of the first of such hubs in a former fire station that has been unoccupied for some years. Most of the time, however, the topics that were addressed in the experiments during the first phase were selected, in a rather top-down manner, involving the municipality and the respective alderman of spatial planning. 
This changed in the second phase when M-LAB launched an open call to all inhabitants of Maastricht to submit their project proposal to be selected as a possible experiment (henceforth referred to as a project). One of the four selection criteria explicitly states that such project proposals need to create more than just economic value. For example, they should also create less tangible value such as social value. However, this criterion, as well as the others, was never clearly stated. As a result, the promised and actual resulting added value is hard to determine. The M-LAB team also experienced difficulties in identifying specific values to be assessed. Research by the URB@Exp project revealed that in the eight cases studied, initiators were more critical about the impact in terms of added public value than M-LAB was. For example, in the artist project of working with traditional ceramics techniques, the first and most important outcome was a cheap space for the artists. The added value for the surrounding neighbourhood, an old industrial neighbourhood being redeveloped, was acknowledged to be rather small.

Reflexivity was stimulated through the creation of the Guideon's group in the first phase, and the network of citymakers and public events in the second stage. Members of this network were invited by M-LAB, approximately twice a month, to a lunch meeting where presentations were given around specific topics relevant to urban development and planning in Maastricht. Often, these presentations were given by members of the network and sometimes they resulted in concrete experiments being initiated up by M-LAB. As a result, the network of citymakers also functioned as a breeding ground for project initiators. However, as the M-LAB team admitted, most of the approximately 60 members of this network, and certainly the most active ones, have a professional background related to urban development (but do not come from the world of large-scale real-estate development). One may wonder then, how effective the network was as a useful mechanism for stimulating openness since it reflected the interest and values of a relatively small group of Maastricht's urban society. Discussions with researchers from URB@Exp also inserted reflexivity into the project by drawing attention to boundary work and the need to find ways to better safeguard public value.

\subsection{Overcoming Resistance to Institutional Innovation and Innovation Achieved}

In analyzing the resistance to innovation by city labs, we have to distinguish three levels against which resistance can be directed: the city lab itself, specific experiments of the city lab (or the way they are done), and the institutional embedment of lessons of the city lab. In the following text, we address each of them.

According to the external project leader of M-LAB's first phase, scepticism about the newly created city lab was higher in the local society than in the municipal apparatus:
"I presented the plans for the Maastricht-LAB to a group of local architects and asked them to join the projects. They were very sceptical and immediately reacted in an old-fashioned way by wanting to know about money. They even did not want to consider the idea."

Resistance may also come from citizens, especially those with established stakes in local urban politics. M-LAB experienced a major conflict with a neighbourhood platform which resisted during the process of the experiment and rejected the proposal of the M-LAB experiment for repurposing a former fire station. Neighbourhood platforms have existed since the 1980s and the city officials have argued on various occasions that they have now become an inadequate instrument for participation that has led to small circles of participation elites in each neighbourhood. Their resistance shows the limits of $M-$ $L A B$ 's role as mediator when different parties are fighting for use of a building. The M-LAB team proceeded with the experiment and developed a new concept of repurposing the building. One of the last collective meetings led to an unexpected voting with all potential users of the building. Almost all of the users did not want to collaborate with the neighbourhood platform. M-LAB advised the public administration and alderman to proceed with realizing the developed concept without the neighbourhood platform, which was approved.

In taking a more facilitative role and actively supporting the projects of initiators, M-LAB encountered some resistance to innovation from bureaucratic municipal organization units. For example, the real-estate department was not too happy with the development of a new rental contract based on turnover rent, or for a new creative hub for start-ups in a temporarily vacant school building (Caracola). These demonstrate moments in which the experimental character of M-LAB projects aiming for new approaches can clash with the bureaucratic apparatus designed to deliver predictable (and legitimate) results without creating an exemplary exception. Nevertheless, this kind of experiences have resulted in a more continuous exchange within the department of spatial planning about the possibility of being less strict with the application of regulatory frameworks.

M-LAB experiments impacted urban planning practices in several ways. Here, the role of the manager of the physical planning department working part-time for the M-LAB was crucial. The manager, first, made facilitating skills part of the profile to be used by the human resource policy, and secondly, initiated a regular meeting to exchange experiences with facilitating projects from outside parties. In addition to receiving training, a group of 20 people of the city meet to discuss concrete projects they were dealing with as city administrators. Process management has become a new competence for city administrators (reflected in the creation of a process manager and the boosting of such competences amongst city administrators. M-LAB member and director of physical 
planning Jos Simons played an important role in this. In terms of policy impact, the M-LAB experiments with comaker spaces fed into the current plans to establish a policy for creative hubs in Maastricht. More generally, the $M-L A B$ activities helped to put the topic of temporary use on the agenda of the department of spatial planning, specifically in connection to organic pre-development, a phase that has not yet been systematically included and exploited by urban planners. The experiment with the gasometer, which was re-opened for special events during a 2-month period, resulted in the idea of developing the whole area. For this, an "area programmer" will be contracted, who will not only investigate the potential of the gas station with experimental events but also of the entire area.

\section{Conclusions}

This paper discusses city labs as a new lab phenomenon in the urban realm. A primary result of the paper is the identification of city labs as a distinct analytical category for looking at urban labs and urban experiments from a planning perspective.

A first characteristic is that city labs are hybrid organizational forms purposefully positioned at the border of local administration and society. Their boundary position helps them to partially evade the established bureaucratic logic of the local administrative apparatus, which is necessary to gain space for experimentation with new approaches. This can be expressed by shared ownership of a city lab by the municipality and other stakeholders. Through their hybrid position, somewhat inside and somewhat outside the local administration, city labs can act as boundary organizations, facilitating interaction between actors from different domains and mediating, but in the best case integrating, the different languages, interests and values of the world of policy, science, local business and citizens.

A second characteristic is that city labs are places of experimental learning and are learning environments for new forms of governance. Regardless of the specific thematic focus within urban development that is chosen, city labs are able to generate insightful lessons into how to reorganize local urban governance arrangements and transcend specific barriers to change. Usually, this learning process is formalized to some extent, for example through periodic evaluation sessions involving actors from the municipality.

Third, city labs are multi-stakeholder settings including the local administration and focus on co-creation. This is a crucial aspect for working in a hybrid organizational setting. Moreover, it connects to a fundamental realization shared by city officials across Europe, namely that municipalities, while acquiring more and more responsibilities throughout the recent decades, lack sufficient resources, capacities, skills and knowledge to address complex urban challenges. Therefore, municipalities have come to a greater realization that they cannot deal with these challenges alone. Hence, the search for enabling multi-stakeholder co-creation processes through city labs stems from the necessity and desire to find integrated solutions.

Fourth, city labs use co-creation in conducting experiments. This is a highly distinctive feature since local governments usually do not engage in experiments but develop and apply procedures that deliver guaranteed results. In the case of experiments, there is potential for failure. From the point of learning, a project has failed if nothing is learned, casting failure in a new light. Failure in terms of expected or wished outcomes can contribute as much to social learning about new approaches as success can. How to structure and implement the learning process as an inherent part of an experimental approach is a vital challenge for city labs.

Fifth and finally, city labs approach complex problems in a multi-disciplinary way, by drawing on knowledge from different disciplines. This may be done in a deliberate way, or simply be the result of opting for a co-creation approach. Mobilizing and integrating different types of knowledge is often a key part of an experiment. In city labs, stakeholders form various domains work together, in an attempt to create value for all those who are involved: city officials, local NGO's, SME's and researchers.

The second result of this paper is a new perspective on collaborative planning in the form of city labs as a vehicle for collaborative planning. The case of M-LAB suggests that experimenting can be a useful way forward for finding practical arrangements for multi-stakeholder collaboration in urban planning. At the same time, city lab experiments can help to keep the focus of collaborative planning on substantive results.

The third result is a better (empirically grounded) understanding of the potential of city labs as experimental learning vehicles for a paradigm shift in urban planning. The potential depends on the setup and circumstances within which a city lab approach is used. We are not suggesting that the experience of Maastricht is representative of and equally applicable to other cities. In the case of Maastricht, useful lessons were learned about the following issues: the temporary use of buildings, the need for co-makers spaces, the benefits of direct engagement with the city, the advantages of a hybrid arrangement of the Lab, the positive value of brokering between the city and urban actors, and the limits of a co-creation approach in case of conflicts of interest. City labs can be a tool for local governments to learn together with other stakeholders in a systematic way about new approaches to urban planning. Beyond being simply an appeal to participation, city labs are practical places for multi-stakeholder co-creation processes. With their hybrid position at the boundary of local government and society, they are well-equipped to bring top-down and bottom-up initiatives together.

However, our case study also points to some limitations of city labs. In its four years of existence, M-LAB 
has initiated and participated in many experiments, but they usually do not address large-scale urban challenges, such as urban sustainability. Public value creation needs to be better secured. Labs constitute an interesting and valuable approach to urban development and planning especially if:

- They are based on strategic learning goals;

- They involve explicit lesson-drawing activities about co-creation and alternative forms of planning;

- Public value creation is an explicit consideration of the projects;

- City planners are involved in the Lab configuration and Lab projects.

More case studies are needed to corroborate the innovative potential of city labs. Comparative research would be useful in this regard. It seems that city labs which are set up with the express purpose of experimenting with new forms of urban planning will achieve more than those that merely stimulate local projects in urban development. For M-LAB the term boundary work is a new concept which appears useful, but which had proven to be a difficult concept. Further work on the nature of boundary work and its usefulness as a theoretical concept is desirable. An additional topic for research could be: how to make city labs more inclusive and socially responsive?

\section{Acknowledgements}

We want to thank the handling editor of the special issue of Urban Planning and four anonymous reviewers for offering extremely useful comments. We are grateful to Tim van Wanroij of M-LAB for offering detailed comments on a previous version of the paper. The paper benefitted from discussions we had in the URB@Exp project with researchers and practitioners from city labs, for which we are thankful.

\section{Conflict of Interests}

The authors declare no conflict of interests.

\section{References}

Almirall, E., \& Wareham, J. (2011). Living labs: Arbiters of mid- and ground-level innovation. Technology Analysis \& Strategic Management, 23(1), 87-102.

Arnstein, S. R. (1969). A ladder of citizen participation. Journal of the American Planning Association, 35(4), 216-224.

Babbie, E. (2008). The basics of social research (4th ed.). Belmont, CA: Thomson Learning.

Barber, B. (2013). If mayors ruled the World. New Haven, CT: Yale University Press.

Bergvall-Kareborn, B., \& Stahlbrost, A. (2009). Living lab: An open and citizen-centric approach for innovation.
International Journal of Innovation and Regional Development, 1(4), 356-370.

Björgvinsson, E., Ehn, P., \& Hillgren, P. A. (2012). Agonistic participatory design: Working with marginalised social movements. CoDesign, 8(2-3), 127-144.

Botero, A., \& Saad-Sulonen, J. (2013). Peer-production in public services: Emerging themes for design research and action. In E. Manzini, \& E. Staszowski (Eds.), Public and collaborative-Exploring the intersection of design, social innovation and public policy (pp. 1-12). Milan: DESIS Network.

Brand, R., \& Gaffikin, F. (2007). Collaborative planning in an uncollaborative world. Planning Theory, 6(3), 282-313.

Bulkeley, H., \& Castán Broto, V. (2013). Government by experiment? Global cities and the governing of climate change. Transactions of the Institute of British Geographers, 38(3), 361-375.

Cash, D. W., Clark, W. C., Alcock, F., Dickson, N. M., Eckley, N., Guston, D. H., . . Mitchell, R. B. (2003). Knowledge systems for sustainable development. Proceedings of the National Academy of Sciences, 100(14), 8086-8091.

Dyer, J. H., \& Singh, H. (1998). The relational view: Cooperative strategy and sources of interorganizational competitive advantage. Academy of Management Review, 23(4), 660-679.

European Union. (2011). Cities of tomorrow: Challenges, visions, ways forward. Brussels: European Commission Directorate General for Regional Policy.

Evans, J. (2011). Resilience, ecology and adaptation in the experimental city. Transactions of the Institute of British Geographers, 36(2), 223-237.

Evans, J., Karvonen, A., \& Raven, R. (2016). The experimental city: New modes and prospects of urban transformation. In J. Evans, A. Karvonen, \& R. Raven (Eds.), The experimental city. Oxon and New York: Routledge.

Gabriel, M. (2014). Making it big. Strategies for scaling social innovations. London: NESTA Foundation.

Gemeente Maastricht. (2012). Structuurvisie Maastricht 2030: Ruimte voor ontmoeting. Maastricht: Gemeente Maastricht.

Gieryn, T. (1983). Boundaries of science. In S. Jasanoff, G. E. Markle, J. C. Peterson, \& T. Pinch (Eds.), Handbook of science and technology studies (pp. 393-443). Thousand Oaks, CA: Sage.

Grönlund, K., Bächtiger, A., \& Setälä, M. (Eds.). (2014). Deliberative mini-publics. Involving citizens in the democratic process. Colchester: ECPR Press.

Guston, D. (2001). Boundary organizations in environmental policy and science: An introduction. Science, Technology \& Human Values, 26(4), 299-408.

Healey, P. (1997). Collaborative planning: Shaping places in fragmented societies. Basingstoke: Palgrave.

Healey, P. (2003). Collaborative planning in perspective. Planning Theory, 2(2), 101-123.

Healey, P. (2006). Urban complexity and spatial strate- 
gies towards a relational planning for our times. New York: Routledge.

Healey, P. (2007). Urban complexity and spatial strategies: Towards a relational planning for our times. London and New York: Routledge.

Hegger, D., De Boer, Y., Offermans, A., Merkx, F., Dieperink, C., Kemp, R., . . . Cörvers, R. (2013). Kenniscocreatie-naar productieve samenwerking tussen wetenschappers en beleidsmakers. Maastricht: Datawyse Universitaire Pers.

Hegger, D., Lamers, M., Van Zeijl-Rozema, A., \& Dieperink, K. (2012). Conceptualising joint knowledge production in regional climate change adaptation projects: Success conditions and levers for action. Environmental Science \& Policy, 18, 52-65.

Hellström Reimer, M., McCormick, K., Nilsson, E., \& Arsenault, N. (2012). Advancing sustainable urban transformation through living labs: Looking to the Öresund region. In Proceedings of the Third International Conference on Sustainable Transitions (pp. 29-31). Copenhagen: DTU.

Hillgren, P. A. (2013). Participatory design for social and public innovation: Living labs as spaces of agonistic experiments and friendly hacking. In E. Manzini, \& E. Staszowski (Eds.), Public and collaborativeExploring the intersection of design, social innovation and public policy (pp. 75-88). Milan: DESIS Network.

Hoogma, R., Kemp, R., Schot, J., \& Truffer, B. (2002). Experimenting for sustainable transport. The approach of strategic niche management. London: E. \& F.N. Spon.

Hoppe, R. (2010). From "knowledge use" towards "boundary work": Sketch of an emerging new agenda for inquiry into science-policy interaction. In R. J. Veld (Ed.), Knowledge democracy. consequences for science, politics, and media (pp. 169-186). Berlin: Springer.

Innes, J. E., \& Booher, D. E. (2010). Planning with complexity: An introduction to collaborative rationality for public policy. London: Routledge.

Karvonen, A., \& van Heur, B. (2014). Urban laboratories: Experiments in reworking cities. International Journal of Urban and Regional Research, 38(2), 379-392.

Kemp, R., Schot, J., \& Hoogma, R. (1998). Regime shifts to sustainability through processes of niche formation. The approach of strategic niche management. Technology Analysis and Strategic Management, 10(2), 175-195.

Kemp, R., \& Rotmans, J. (2009), Transitioning policy: Coproduction of a new strategic framework for energy innovation policy in the Netherlands. Policy Sciences, 42(4), 303-322.

Kemp, R., \& van den Bosch, S. (2006). Transitieexperimenten: Praktijkexperimenten met de potentie om bij te dragen aan transities. Utrecht: Kenniscentrum voor Duurzame Systeeminnovaties en Transities (KCT).

Kenniscentrum Stedelijke Vernieuwing, \& NICIS Institute. (2012). Essay: Stedelijke vernieuwing op uitnodiging [Essay: Urban renewal on request]. Wormerveer:
Zwaan Printmedia.

Levy, J. M. (2016). Contemporary planning. London \& New York: Routledge.

Leminen, S., Westerlund, M., \& Nyström, A. (2012). Living labs as open-innovation networks. Technology Innovation Management Review, 2(9), 6-11.

McGuirk, P., Dowling, R., Brennan, C., \& Bulkeley, H. (2015). Urban carbon governance experiments: The role of Australian local governments. Geographical Research, 53, 39-52.

Meadowcroft, J. (2007). Who is in charge here? Governance for sustainable development in a complex world. Journal of Environmental Policy and Planning, 9(3-4), 299-314.

Pohl, C., \& Hadorn, G. H. (2008). Methodological challenges of transdisciplinary research. Natures Sciences Sociétés, 16(2), 111-121.

Prahalad, C. K., \& Ramaswamy, V. (2004). Co-creation experiences: The next practice in value creation. Journal of Interactive Marketing, 18(3), 5-14.

Reich, M. (1975). A noisy tale of two cities. Planning, 41(8), 8-11.

Schliwa G., \& McCormick, K. (2016). Living labs: Users, citizens and transitions. In J. Evans, A. Karvonen, \& R. Raven (Eds.), The experimental city (pp. 163-168). Oxon and New York: Routledge.

Sengers, F., Berkhout, F., Wieczorek, A., \& Raven, R. (2016). Experimenting in the city: Unpacking notions of experimentation for sustainability. In J. Evans, A. Karvonen, \& R. Raven (Eds.), The experimental city (pp. 15-31). Oxon \& New York: Routledge.

Thomke, S. H. (2003). Experimentation matters. Unlocking the potential of new technologies for innovation. Harvard Business School Press.

Van de Ven, A. H. (1986). Central problems in the management of innovation. Management Science, 32(5), 590-607.

Van de Ven, A. H., Polley, E. E., Garud, R., \& Venkataraman, S. (1999). The innovation journey. New York: Oxford University Press.

Veeckman, C., Schuurman, D., Leminen, S., \& Westerlund, M. (2013). Linking living lab characteristics and their outcomes: Towards a conceptual framework. Technology Innovation Management Review, 3(12), 6-15.

Voytenko, Y., McCormick, K., Evans, J., \& Schliwa, G. (2016). Urban living labs for sustainability and low carbon cities in Europe: Towards a research agenda. Journal of Cleaner Production, 123, 45-54.

Waste, R. J. (1987). Power and pluralism in American cities. Researching the urban laboratory. Westport, CT: Greenwood Press.

Westley, F., Goebey, S, \& Robinson, K. (2012). What is a change lab/design lab for social innovation; $a$ thought piece for the development of a new approach for building capacity for social innovation in Canada. Waterloo: Waterloo Institute of Social Innovation and Resilience. Retrieved from http://sigeneration.ca/ documents/Paper_FINAL_LabforSociallnnovation.pdf 


\section{COGITATIO}

\section{About the Authors}

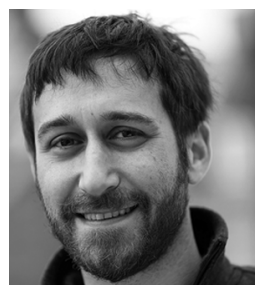

Christian Scholl is a post-doctoral research fellow at ICIS, Maastricht University, and coordinator of the Urb@Exp research project about new forms of participatory urban governance and sustainable urban development. With a background in political science and philosophy, his research interests revolve around urban social movements and participatory democracy. In his previous research, he examined the climate justice movement, spatial aspects of anti-globalization protests in Europe and new forms of urban control.

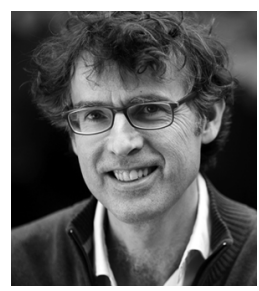

René Kemp is professor of innovation and sustainable development at the ICIS research institute of Maastricht University and professorial fellow at UNU-MERIT. He is an innovation researcher with a background in economics and an interest in policy, history, society, theory and research methodology. He is an expert of sustainability transitions, governance for sustainable development, and policy evaluation in relation to eco-innovation. He currently works on transformative social innovation and the role of urban labs in urban planning and city making in the TRANSIT and URB@Exp projects. 